\title{
Papers
}

\section{Prognosis of angina with and without a diagnosis: 11 year follow up in the Whitehall II prospective cohort study}

\author{
Harry Hemingway, Martin Shipley, Annie Britton, Michael Page, Peter Macfarlane, Michael Marmot
}

\begin{abstract}
Objective To investigate the prognosis of angina among people with and without diagnosis by a doctor and an abnormal cardiovascular test result.

Design Prospective cohort study with a median follow up of 11 years.

Setting 20 civil service departments originally located in London.

Participants 10308 civil servants aged $35-55$ years at baseline.

Main outcome measures Recurrent reports of angina; quality of life (SF-36 physical functioning); non-fatal myocardial infarction; death from any cause $(\mathrm{n}=344)$.

Results 1158 (11.4\%) participants developed angina, and $813(70 \%)$ had no evidence of diagnosis by a doctor at the time of the initial report. Participants without a diagnosis had an increased risk of impaired physical functioning (age and sex adjusted odds ratio of 2.36 (95\% confidence interval 1.91 to 2.90$)$ ) compared with those who had neither angina nor myocardial infarction throughout follow up. Among reported cases of angina without a diagnosis, the $15.5 \%$ with an abnormality on a study electrocardiogram had an increased risk of death (hazard ratio 2.37 (1.16 to 4.87)). These effects were similar in magnitude to those in participants with a diagnosis of angina.

Conclusion Undiagnosed angina was common and had an adverse impact on prognosis comparable to that of diagnosed angina, particularly among people with electrocardiographic abnormalities. Efforts to improve prognosis among people with angina should take account of this submerged clinical iceberg.
\end{abstract}

\section{Introduction}

During a period of declining incidence of myocardial infarction, the prevalence of angina remains high, and consultations for angina in primary care have increased. ${ }^{1}$ Government and professional bodies increasingly emphasise the importance of systematic identification and investigation of people with new onset angina on the basis of an assessment of prognosis. $^{2-4}$

However, people with angina do not necessarily seek medical care. ${ }^{5-7}$ The size and prognosis of this group has not been assessed in a contemporary prospective cohort. Population based studies show that the combination of angina identified by questionnaire and an abnormality on a resting electrocardiogram identifies groups with increased risk of death. ${ }^{89}$ Whether this risk is confined to patients who have sought medical care and have a diagnosis from a doctor (visible clinical iceberg) or if it extends to those without a diagnosis by a doctor (submerged clinical iceberg) is not known. ${ }^{10}$ The impact of undiagnosed angina on recurrent reports of angina and physical functioning is unclear.

Our objective therefore was to investigate the prognosis of angina among people with and without a diagnosis by a doctor and an abnormal cardiovascular test result. We defined prognosis by four outcomes: death, myocardial infarction, recurrent reports of angina, and functional status.

\section{Method}

\section{Participants}

We invited all non-industrial civil servants aged 35-55 years working in the London offices of 20 departments to participate in this study. The final cohort consisted of 10308 participants (3413 women) with an overall response rate of $73 \% .{ }^{11}$ We obtained written informed consent from participants to examine clinical records. Participants completed questionnaires at five phases of data collection between 1985 and 1999 (fig A on bmj.com). At phase 5, 7830 participants completed a questionnaire $(76 \%$ response rate from phase 1$)$. At each phase we used the seven item Rose angina questionnaire to define angina independent of contact with medical care. ${ }^{12}$

\section{Diagnosis of angina by a doctor}

We obtained evidence of a diagnosis of angina from questionnaire items on diagnosis (four items), investigation (two items), and treatment (two items) (see bmj.com). We examined general practitioner and hospital records for details of diagnoses and abnormal test results among participants reporting positively on any of these eight questionnaire items. We also sought clinical records where the civil service gave a reason for sickness absence as angina or myocardial infarction or when the spell of absence exceeded 21 days.

\section{Abnormal test results}

Regardless of contact with medical care, we investigated each participant with a resting 12 lead
International Centre for Health and Society, Department of Epidemiology and Public Health, University College London Medical School, London WC1E 6BT Harry Hemingway reader in clinical epidemiology

Martin Shipley senior lecturer in medical statistics Annie Britton lecturer in epidemiology Michael Page research nurse Michael Marmot professor of epidemiology and public health

University of Glasgow, Department of Medical Cardiology, Royal Infirmary, Glasgow G31 2ER Peter Macfarlane professor of electrocardiology

Correspondence to: H Hemingway h.hemingway@ public-health.ucl.ac.uk

bmj.com 2003;327:895

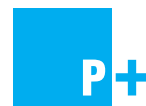

Additional tables, figures, and questionnaire items appear on bmi.com 
electrocardiogram at phases 1,3 , and 5 . We defined abnormal results as $Q$ waves (Minnesota codes 1-1 to 1-3), ST depression (4-1 to 4-4), inverted T waves (5-1 to 5-3), or left bundle branch block (7-1). ${ }^{13}$ Additionally, among participants who had sought medical care, we defined abnormal test results as the presence of one or more diseased vessels at coronary angiography or $\geq 1$ $\mathrm{mm}$ ST depression on exercise electrocardiogram or a reversible defect on stress imaging.

\section{Outcomes: classification of angina and recurrent reports}

We classified angina according to evidence of diagnosis by a doctor and the presence of an abnormal test result (table 1). We made chronological listings of each item of epidemiological and clinical record data. We coded pairwise combinations of evidence from two columns in the table in a hierarchy starting from a clinical record of diagnosis of angina plus an abnormal coronary angiogram at the top (first row) down to angina identified by the Rose angina questionnaire ("Rose angina") plus a normal study electrocardiogram at the bottom (last row). Two independent coders assigned dated codes for each report of angina. In the rare event of disagreement a third coder adjudicated. We defined a report of angina at each date that new evidence became available, but we allocated only one code, the highest, within any 28 day period. For participants reporting Rose angina at follow up but not at the previous phase, we used the mid-point date as the date of the report.

Outcomes: mortality, non-fatal myocardial infarction and physical functioning

Almost all (99.9\%) participants were flagged at the NHS Central Registry, which notified us of dates of death. We defined non-fatal myocardial infarction by following the MONICA criteria of typical symptoms, enzyme abnormalities, and electrocardiographic changes. ${ }^{14}$ We assessed physical functioning at phase 5 in 6839 participants by using the 10 item scale of the SF-36 health survey. ${ }^{15} 16$ This scale asks: "Does your health now limit you in these [10 different] activities?" The activities range from running, through climbing stairs, to bathing and dressing. The scale ranges from 0 (worst) to 100 (best) and has previously been validated against risk factors, severity of angina, and time on an exercise electrocardiogram. ${ }^{16}{ }^{17}$

\section{Statistical analysis}

We compared participants with four categories of angina, defined by the presence or absence of a diagnosis by a doctor or an abnormal test result, with participants who did not have angina or a myocardial infarction throughout follow up. All analyses concern incident angina among people without previous myocardial infarction. We excluded from all analyses 102 participants with angina or myocardial infarction $(\mathrm{n}=224$ reports) before phase 1 and 15 participants not flagged at the Central Registry. By 31 December 1999, 344 deaths had occurred among the remaining 10191 participants (2.9 per 1000 person years). To examine the prognosis of participants after their first report of angina, we calculated the risk (probability) of specified events occurring in the next five years from their rate of occurrence. We calculated person years of survival by using the date of phase 1 and the dates of angina events and death or censoring at the end of 1999. We described the relation between types of angina and subsequent mortality with hazard ratios and $95 \%$ confidence intervals, calculated by using time dependent Cox's proportional hazards models that allowed for transitions during the follow up period, but only to a more severe category of angina. Thus the numbers of participants in the categories of angina in tables 1 and 4 differ. We defined impaired SF-36 physical functioning as below the lowest sex specific quartile $(<86$ for men and $<71$ for women) and used logistic regression to determine odds ratios of impaired physical functioning.

\section{Results}

Table 1 shows that 1158 (11.4\%) of 10191 participants developed angina. We found 2772 reports of angina, so $1614(58 \%)$ of angina reports were recurrent (fig B on bmj.com).

\section{Recurrent angina and non-fatal myocardial infarction}

At the time of the first report of angina, 718/970 (74\%) participants had no evidence of a diagnosis of angina by a doctor (table 2). Of these, $470(65 \%)$ reported angina again during follow up and remained without a diagnosis. Among participants with an abnormal test result, the absolute risk of non-fatal myocardial infarc-

Table 1 Classification of angina according to evidence of diagnosis by doctor and abnormal test result

\begin{tabular}{|c|c|c|c|c|c|c|c|}
\hline \multirow{2}{*}{$\begin{array}{l}\text { Evidence of } \\
\text { diagnosis of angina } \\
\text { by doctor? }\end{array}$} & \multirow[b]{2}{*}{$\begin{array}{c}\text { Abnormal test } \\
\text { result? }\end{array}$} & \multicolumn{2}{|c|}{ Epidemiological study data } & \multicolumn{2}{|c|}{ Clinical record data } & \multirow{2}{*}{$\begin{array}{c}\text { No of } \\
\text { participants } \\
\text { (total=1158) }\end{array}$} & \multirow{2}{*}{$\begin{array}{c}\text { No of } \\
\text { reports* } \\
\text { (total=2772) }\end{array}$} \\
\hline & & $\begin{array}{l}\text { Self report } \\
\text { questionnaire }\end{array}$ & $\begin{array}{l}\text { Abnormal test } \\
\text { result: study ECG }\end{array}$ & Diagnosis & $\begin{array}{c}\text { Abnormal test } \\
\text { result }\end{array}$ & & \\
\hline \multirow[t]{6}{*}{$\begin{array}{l}\text { Yes ("visible } \\
\text { iceberg") }\end{array}$} & Yes & - & - & Angina & $\begin{array}{c}\text { Coronary } \\
\text { angiography } \dagger\end{array}$ & 134 & 178 \\
\hline & & - & - & Angina & Exercise ECG‡ & 65 & 76 \\
\hline & & - & Abnormal§ & Angina & - & 51 & 63 \\
\hline & & $\begin{array}{l}\text { Diagnosis of angina } \\
\text { or use of nitrate }\end{array}$ & Abnormal§ & - & - & 105 & 170 \\
\hline & No & - & Normal & Angina & - & 125 & 147 \\
\hline & & $\begin{array}{l}\text { Diagnosis of angina, } \\
\text { use of nitrate, or } \\
\text { sickness absence }\end{array}$ & Normal & - & - & 252 & 405 \\
\hline \multirow{2}{*}{$\begin{array}{l}\text { No ("submerged } \\
\text { iceberg") }\end{array}$} & Yes & Rose angina & Abnormal§ & - & - & 174 & 268 \\
\hline & No & Rose angina & Normal & - & - & 768 & 1465 \\
\hline
\end{tabular}

ECG=electrocardiogram

${ }^{*}$ One participant may have more than one report of angina.

†One or more diseased vessel on coronary angiography.

$\ddagger \geq 1 \mathrm{~mm}$ horizontal or downward sloping ST depression on exercise ECG or reversible deficit on stress imaging

\$Minnesota codes 1-1 to 1-3 (Q waves), 4-1 to 4-4 (ST depression), 5-1 to 5-3 (T wave inversion), or 7-1 (left bundle branch block) in most recent ECG. 
Table 2 Percentage risk (number) of most serious* subsequent event over five years in participants with angina as a first report

\begin{tabular}{|c|c|c|c|c|c|c|c|c|}
\hline \multirow[b]{4}{*}{ Type of first report† } & \multirow[b]{4}{*}{$\begin{array}{c}\text { No of } \\
\text { participants }\end{array}$} & \multicolumn{6}{|c|}{ Type of most serious event over five years' follow up } & \multirow[b]{4}{*}{ None } \\
\hline & & \multirow[b]{3}{*}{$\begin{array}{l}\text { Death from } \\
\text { any cause }\end{array}$} & \multirow[b]{3}{*}{$\begin{array}{l}\text { Myocardial } \\
\text { infarction }\end{array}$} & \multicolumn{4}{|c|}{ Angina } & \\
\hline & & & & \multicolumn{2}{|c|}{ Diagnosis by doctor } & \multicolumn{2}{|c|}{ No diagnosis by doctor } & \\
\hline & & & & $\begin{array}{l}\text { Abnormal } \\
\text { test (any) }\end{array}$ & $\begin{array}{l}\text { No abnormal } \\
\text { test }\end{array}$ & $\begin{array}{l}\text { Abnormal test } \\
\text { (study ECG) }\end{array}$ & $\begin{array}{l}\text { No abnormal } \\
\text { test }\end{array}$ & \\
\hline \multicolumn{9}{|c|}{ Angina (diagnosis by doctor): } \\
\hline Abnormal test (any) & 80 & $0.13(8)$ & $0.16(10)$ & $0.26(17)$ & $0.16(10)$ & $0.07(4)$ & $0.02(1)$ & $0.20(30)$ \\
\hline No abnormal test & 172 & $0.03(5)$ & $0.17(27)$ & $0.24(39)$ & $0.21(34)$ & $0.01(2)$ & $0.03(5)$ & $0.31(60)$ \\
\hline \multicolumn{9}{|c|}{ Angina (no diagnosis by doctor): } \\
\hline $\begin{array}{l}\text { Abnormal test (study } \\
\text { ECG) }\end{array}$ & 85 & $0.10(7)$ & $0.15(11)$ & $0.11(8)$ & $0.00(0)$ & $0.46(42)$ & $0.01(1)$ & $0.17(16)$ \\
\hline No abnormal test & 633 & $0.04(22)$ & $0.07(36)$ & $0.05(24)$ & $0.05(24)$ & $0.07(34)$ & $0.54(393)$ & $0.18(100)$ \\
\hline $\begin{array}{l}\text { No angina or myocardial } \\
\text { infarction throughout } \\
\text { follow up }\end{array}$ & 9066 & $0.01(297)$ & NA & NA & NA & NA & NA & $0.99(8769)$ \\
\hline
\end{tabular}

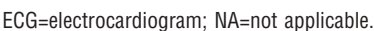

${ }^{\star}$ Seriousness of event ranged from death (most serious), through myocardial infarction and angina with diagnosis by doctor, to angina without diagnosis by doctor (least serious). First events occurring at or after phase 5 have been excluded.

†ln 155 participants the first event was myocardial infarction.

tion was similar in those without a diagnosis by a doctor $(15 \%)$ and those with a diagnosis $(16 \%)$.

\section{Impaired physical functioning}

Participants with angina had an increased risk of impaired physical functioning at phase 5 (mean follow up seven years) compared with participants who did not have angina or myocardial infarction throughout follow up (table 3). The age and sex adjusted odds ratio was similar in participants without a diagnosis by a doctor (2.36 (95\% confidence interval 1.91 to 2.90$)$ ) and those with a diagnosis (3.19 (2.25 to 4.53)). Separate analyses showed that the prospective impact of angina on functional impairment was the same in women and men (table A on bmj.com). Angina diagnosed within the seven years before functional assessment had a similar impact on functional impairment to angina diagnosed earlier (table $\mathrm{B}$ on bmj.com). As the median year of phase 5 was 1998, this approximates to diagnoses before or after 1991.

\section{Survival}

Mortality was increased in people with undiagnosed angina and an abnormal test result, compared with participants with neither angina nor myocardial infarction (table 4). Abnormal study electrocardiograms occurred in 268/1733 (15.5\%) reported cases of undiagnosed angina (table 1). The age and sex adjusted hazard ratio for mortality in this group was 2.37 (1.16 to $4.87, \mathrm{P}=0.02$ ). Among participants with a diagnosis by a doctor, we found some evidence for adverse survival in those with an abnormal test result (hazard ratio 1.83 (0.95 to $3.52, \mathrm{P}=0.07)$ ).

\section{Discussion}

In this population based study, followed throughout the 1990s, more than half of people with angina had no evidence of diagnosis by a doctor. Among this group, an abnormal study electrocardiogram was common and was associated with worse survival. The increased risk of death and non-fatal myocardial infarction in people with angina and an abnormal test result was similar in magnitude in participants with and without a diagnosis. Recurrent reports of angina and impaired physical functioning were common in the undiagnosed group. The consistency of our findings across all four outcomes provides evidence for a prognostically important submerged clinical iceberg of people with angina.

\section{Angina without a diagnosis}

No previous prospective studies during the 1990s have estimated the frequency and prognosis of angina without diagnosis by a doctor. Primary care consultations for angina rose between 1981 and $1991,{ }^{1}$ during a period of declining incidence of myocardial infarction. Most patients with symptoms of acute myocardial infarction seek medical care and obtain a diagnosis from a doctor-the submerged clinical iceberg is small. Our study shows that this is not true for angina. Our findings indicate that primary care disease registers, required by national policy, ${ }^{2}$ are underestimating the

Table 3 Impaired physical functioning at phase 5 by type of first angina report

\begin{tabular}{|c|c|c|c|}
\hline Type of first angina report & No of participants & $\begin{array}{l}\text { No with poor physical } \\
\text { functioning }\end{array}$ & $\begin{array}{l}\text { Odds ratio }(95 \% \mathrm{CI}) \\
\text { adjusted for age and sex }\end{array}$ \\
\hline $\begin{array}{l}\text { No angina or myocardial } \\
\text { infarction throughout } \\
\text { follow up }\end{array}$ & 6200 & 1374 & 1.00 \\
\hline \multicolumn{4}{|l|}{ Angina (diagnosis by doctor): } \\
\hline Abnormal test (any) & 53 & 24 & 2.29 (1.32 to 3.98$)$ \\
\hline No abnormal test & 133 & 68 & 3.19 (2.25 to 4.53$)$ \\
\hline \multicolumn{4}{|c|}{ Angina (no diagnosis by doctor): } \\
\hline $\begin{array}{l}\text { Abnormal test (study } \\
\text { electrocardiogram) }\end{array}$ & 39 & 18 & 2.75 (1.45 to 5.22$)$ \\
\hline No abnormal test & 414 & 169 & 2.36 (1.91 to 2.90$)$ \\
\hline
\end{tabular}

Table 4 All cause mortality by type of angina report

\begin{tabular}{|c|c|c|c|c|}
\hline Type of angina report & $\begin{array}{c}\text { No of } \\
\text { participants } \dagger\end{array}$ & No of deaths & $\begin{array}{c}\text { Rate }^{\star} \text { per } 1000 \\
\text { person years at risk }\end{array}$ & $\begin{array}{c}\text { Hazard ratio* } \\
(95 \% \mathrm{CI})\end{array}$ \\
\hline $\begin{array}{l}\text { No angina or } \\
\text { myocardial } \\
\text { infarction } \\
\text { throughout follow } \\
\text { up }\end{array}$ & 8949 & 296 & 2.6 & 1.00 \\
\hline \multicolumn{5}{|c|}{ Angina (diagnosis by doctor): } \\
\hline Abnormal test (any) & 201 & 10 & 4.9 & 1.83 (0.95 to 3.52$)$ \\
\hline No abnormal test & 231 & 5 & 2.4 & $0.90(0.37$ to 2.21$)$ \\
\hline \multicolumn{5}{|c|}{ Angina (no diagnosis by doctor): } \\
\hline $\begin{array}{l}\text { Abnormal test } \\
\text { (study } \\
\text { electrocardiogram) }\end{array}$ & 150 & 8 & 6.0 & 2.37 (1.16 to 4.87$)$ \\
\hline No abnormal test & 706 & 20 & 2.8 & $1.12(0.71$ to 1.78$)$ \\
\hline
\end{tabular}

*Adjusted for age and sex.

†No of participants contributing person years in each category of angina. 
burden of angina in the general population. Consistent with a previous study,$^{18}$ employment grade did not influence the probability of having a diagnosis (data not shown).

Several reasons exist for a lack of diagnosis. A person with angina may not seek medical care. Little is known about factors predicting uptake of medical care and the negotiation of a diagnosis. ${ }^{7}$ Once medical care has been sought, the doctor may miss or not record the diagnosis-a group that this study was not able to identify. If this were an important reason for the lack of diagnosis then the adverse prognosis suggests a need for improvements in the diagnostic ability of clinicians.

\section{Prognosis of angina}

A strength of our study lies in the repeated assessments of angina status made over prolonged follow up. An estimated $60 \%$ of the undiagnosed group reported angina again but remained without a diagnosis over five years of follow up. The British regional heart study found that Rose angina reported on two occasions was associated with a greater risk of fatal and non-fatal myocardial infarction than was angina reported on only one occasion. ${ }^{6}$ Recurrent reports of angina may represent severe disease or ongoing ischaemia, as Rose proposed. ${ }^{19}$

As physical exercise is a common precipitant of angina, impairments in physical activities of everyday living constitute a major dimension of prognosis of angina. The presence of angina at baseline was associated with worse physical functioning at follow up, as assessed by a generic measure of health related quality of life. Importantly, this effect was similar in people with and without a diagnosis from a doctor and among both women and men.

We investigated all participants with resting electrocardiography and found adverse survival in people with angina without a diagnosis from a doctor in the presence of an abnormal resting electrocardiogram. Importantly, this effect was similar in magnitude (doubling of mortality) in those people with diagnosed angina who had an abnormal test result. Although many general practices have facilities for electrocardiography, the prognostic importance of common abnormalities is underappreciated. ${ }^{8}$

\section{Impact of medical care and policy implications}

Secondary prevention and revascularisation improve outcomes in angina, but only in people with a diagnosis. Underuse of investigation and treatment, widespread in the United States and the United Kingdom, ${ }^{20}{ }^{21}$ may have an adverse effect on outcomes. ${ }^{22}$ We found no evidence that the impact of diagnosed angina on long term functional impairment improved over time. Guidelines in the United States and the United Kingdom recommend that all people with angina should undergo resting electrocardiography in order to identify high risk groups for further investigation and treatment. ${ }^{2}{ }^{4}$ The cost effectiveness of systematic case finding (with questionnaire) and risk assessment (with electrocardiography) of people with angina in the general population awaits investigation.

\section{Conclusion}

Among people with angina, a submerged clinical iceberg is associated with adverse prognosis across a range of outcomes. Reducing the population burden of

\section{What is already known on this topic}

Systematic identification and investigation of people with angina is recommended by government and professional bodies

Many people with angina do not seek medical care, but the size and prognosis of this group has not been prospectively investigated in a contemporary cohort

\section{What this study adds}

Over half of participants with angina remained without a diagnosis on follow up

Physical functioning was impaired to a similar degree in people with and without a diagnosis of angina

Among people with an abnormal test result, the impact on mortality was similar in those with and without a diagnosis

angina requires consideration of people who have yet to be given a diagnosis.

We thank all participating civil service departments and their welfare, personnel, and establishment officers; Elizabeth McCloy, George Sorrie, and Adrian Semmence of the Civil Service Occupational Health Service; the Civil Service Central Monitoring Service and Frank O'Hara; the Council of Civil Service Unions; and all participating civil servants. We also thank all members of the Whitehall II study team, particularly Amanda Nicholson, Lynn Toon, Rhonda Holt, Umesh Sharma, and Rob Canner.

Contributors: $\mathrm{HH}$ posed the question, designed the classification of angina, and wrote the first draft of the paper. MS carried out all the statistical analyses. MP carried out the collection and coding of the data. PM was responsible for coding the electrocardiograms. MM is the principal investigator on the Whitehall II study. MM, AB, and all coauthors made significant contributions to early and final drafts. $\mathrm{HH}$ is the guarantor.

Funding: The study was supported by grants from the Medical Research Council; Health and Safety Executive; British Heart Foundation; National Heart Lung and Blood Institute (2RO1 HL36310); Agency for Health Care Policy and Research (5 RO1 HS06516); National Institute on Aging (RO1 AG13196-02); Institute for Work and Health, Canada; Volvo Research Foundation, Sweden; New England Medical Centre-Division of Health Improvement; Department of Health; and the John D. and Catherine T. MacArthur Foundation research networks on successful midlife development and socioeconomic status. $\mathrm{HH}$ is supported by a national career scientist award from the Department of Health. MS is supported by the British Heart Foundation. MM is supported by an MRC research professorship.

Competing interests: None declared.

Ethical approval: Each phase of the Whitehall II study has received ethical approval from the research ethics committee of UCL Hospitals.

McCormick A, Fleming D, Charlton G. Morbidity statistics from general practice: fourth national study 1991-1992. London: HMSO, 1995

Department of Health. National service framework for coromary heart disease: modern standards and service models. London: Stationery Office, 2000.

Eccles M, Rousseau N, Adams P, Thomas L. Evidence-based guideline for the primary care management of stable angina. Fam Pract 2001;18:21722.

Gibbons RJ, Abrams J, Chatterjee K, Daley J, Deedwania PC, Douglas JS, et al. ACC/AHA 2002 guideline update for the management of patients with chronic stable angina-summary article: a report of the American College of Cardiology/American Heart Association task force on practice guidelines. J Am Coll Cardiol 2003;41:159-68.

5 Lampe FC, Walker M, Lennon LT, Whincup PH, Ebrahim S. Validity of a self-reported history of doctor-diagnosed angina. J Clin Epidemiol 1999;52:73-81. 
6 Lampe FC, Whincup PH, Shaper AG, Wannamethee SG, Walker M, Ebrahim S. Variability of angina symptoms and the risk of major ischemic heart disease events. Am J Epidemiol 2001;153:1173-82.

7 Gardner K, Chapple A. Barriers to referral in patients with angina: qualitative study. BMJ 1999;319:418-21

8 Daviglus ML, Liao Y, Greenland P, Dyer AR, Liu K, Xie X, et al Association of nonspecific minor ST-T abnormalities with cardiovascular mortality: the Chicago Western Electric study [see comments]. JAMA 1999;281:530-6.

9 Hemingway H, Shipley M, Macfarlane P, Marmot M. Impact of socioeconomic status on coronary mortality in people with symptoms, electrocardiographic abnormalities, both or neither: the original Whitehall study 25 year follow up.J Epidemiol Community Health 2000; 54:510-6.

10 Last JM. The iceberg: "completing the clinical picture" in general practice. Lancet 1963;28-31.

11 Marmot MG, Davey Smith G, Stansfeld SA, Patel C, North F, Head J, et al. Health inequalities among British civil servants: the Whitehall II study. Lancet 1991;337:1387-93.

12 Rose G, Blackburn H, Gillum RF, Prineas RJ. Cardiovascular survey methods. Geneva: World Health Organization, 1982.

13 Macfarlane PW, Latif S. Automated serial ECG comparison based on the Minnesota code. J Electrocardiol 1996;29(suppl):29-34.

14 Tunstall-Pedoe H, Kuulasmaa K, Amouvel P, Arveiler D, Rajakangas AM, Pajak A. Myocardial infarction and coronary deaths in the World Health Organization MONICA project: registration procedures, event rates, and case-fatality rates in 38 populations from 21 countries in four continents. Circulation 1994;90:583-612.
15 Ware JE, Snow KK, Kosinski M, Gandek B. SF-36 health survey manual and inter pretation guide. Boston: New England Medical Center, 1993.

16 Stafford M, Hemingway H, Stansfeld S, Brunner E, Marmot M. Behavioural and biological correlates of physical functioning in middle aged office workers: the Whitehall II study.J Epidemiol Community Health 1998;52:353-8.

17 Pocock SJ, Henderson RA, Clayton T, Lyman GH, Chamberlain DA. Quality of life after coronary angioplasty or continued medical treatment for angina: three-year follow-up in the RITA-2 trial. J Am Coll Cardiol 2000;35:907-14.

18 Richards H, McConnachie A, Morrison C, Murray K, Watt G. Social and gender variation in the prevalence, presentation and general practitioner provisional diagnosis of chest pain. J Epidemiol Community Health 2000;54:714-8.

19 Rose G. Variability of angina: some implications for epidemiology. $\mathrm{Br} \mathrm{J}$ Prev Soc Med 1968;22:12-5.

20 Martin RM, Hemingway H, Gunnell D, Karsch KR, Baumbach A, Frankel S. Population need for coronary revascularisation: are national targets for England credible? Heart 2002;88:627-33.

21 Clarke KW, Gray D, Hampton JR. Implication of prescriptions for nitrates: 7 year follow up of patients treated for angina in general practice. Br Heart J 1994;71:38-40.

22 Hemingway H, Crook AM, Feder G, Banerjee S, Dawson JR, Magee P, et al. Underuse of coronary revascularization procedures in patients considered appropriate candidates for revascularization. $N$ Engl J Med 2001;344:645-54.

(Accepted 31 July 2003) 